\title{
PENERAPAN MODEL PEMBELAJARAN KOOPERATIF TIPE STAD UNTUK MENINGKATKAN HASIL BELAJAR SISWA PADA MATA PELAJARAN IPS SISWA KELAS V SD MATERI KERAJAAN DAN PENINGGALAN HINDU DI INDONESIA
}

\author{
Antonius Alam Wicaksono ${ }^{1}$, Hanif Fikri Bariska \\ Pendidikan Matematika FIP Universitas Tribhuwana Tunggadewi \\ E-mail: antoniuseducator@gmail.com ${ }^{1}$
}

\begin{abstract}
Abstrak
Bertolak dari latar belakang tersebut rumusan masalahnya adalah : 1) Apakah penerapan model kooperatif tipe STAD dapat meningkatkan hasil belajar Pada Pembelajaran Kerajaan dan Peninggalan Hindu di Indonesia Mata Pelajaran Ilmu Penetahuan Sosial, 2) Bagaimana pengaruh penerapan model STAD dapat meningkatkan hasil belajar Pada Pembelajaran Kerajaan dan Peninggalan Hindu di Indonesia Mata Pelajaran Ilmu Pengetahuan Sosial. Untuk menjawab pertanyaan itu peneliti menggunakan metode Tes (pre test dan post test) dan metode observasi dalam pengumpulan data sebagai bukti atau fakta dalam penelitian ini. Hasil yang dalam penelitian "Penerapan Model Pembelajaran Kooperatif Tipe STAD Untuk meningkatkan Hasil Belajar Siswa Pada Mata Pelajaran Ilmu Pengetahuan Sosial Kelas V SDN Dinoyo I Malang Materi Kerajaan dan Peninggalan Hindu di Indonesia "lebih meningkat. Hal ini terlihat dari nilai rata-rata siswa sebelum menggunakan model Pembelajaran KooperatifTipe STAD adalah 50 dan setelah menggunakan model Pembelajaran Kooperatif Tipe STAD nilai rata-rata siswa adalah 84,61 . Sedangkan persentase peserta didik yang tertarik saat pembejaran tipe STAD sebesar $100 \%$.
\end{abstract}

Kata kunci: STAD, Hasil Belajar, IPS

\begin{abstract}
Based on the background, the formulation of the problem is: 1) Whether the application of STAD type cooperative model can improve learning outcomes on the Kingdom and Hindu Learning Lessons in Indonesia Social Science Subjects, 2) How the effect of STAD model application can improve learning outcomes In Kingdom Learning and Hindu Relics in Indonesia Social Science Subjects. To answer the question the researcher uses the test method (pre test and post test) and observation method in data collection as evidence or fact in this research. The results of the study "Application of Cooperative Learning Model Type STAD To Improve Student Results On Social Sciences Subjects Class V SDN Dinoyo I Malang The Kingdom and Hindu Relics in Indonesia" is increasing. This can be seen from the average score of the students before using the STAD Cooperative Learning ModelThe STAD model is 50 and after using the STAD Type Co-operative Learning model the average score of students is 84.61 . While the percentage of learners who are interested when STAD type pursuit of $100 \%$.
\end{abstract}

Keywords: STAD, improve learning outcomes, Social Science 


\section{PENDAHULUAN}

Sesuai observasi yang dilakukan oleh peneliti di SD Negeri Dinoyo I Malang, permasalahan yang perlu mendapat solusi adalah rendah dan kurang meratanya daya serap siswa kelas 5 pada mata pelajaran IPS khususnya kompetensi dasar mengenal makna peninggalan-peninggalan sejarah yang berskala nasional dari masa HinduBudha dan Islam di Indonesia. Dalam penelitian ini, penulis berkolaborasi dengan guru SD Negeri Dinoyo I Malang dalam meningkatkan hasil belajar siswa pada mata pelajaran IPS siswa kelas V.

Kolaborasi ini menerapkan model pembelajaran kooperatif tipe STAD, sebagai alternatif atau solusi dalam pemecahan masalah yang dihadapi oleh guru dalam melaksanakan proses pembelajaran materi kenampakan alam di lingkungan kabupaten/kota dan provinsi serta hubungannya dengan keragaman social dan budaya di kelas V. Dengan menyadari gejala-gejala atau kenyataan tersebut diatas, maka dalam penelitian ini fokus terhadap peningkatan hasil belajar mata pelajaran IPS dengan model pembelajaran STAD.

\section{METODE PENELITIAN}

Data-data penelitian yang diperoleh melalui teknik-teknik pengumpulan data seperti yang diuraikan pada bab satu, yaitu teknik tes dan observasi. Dalam penelitian ini teknik pengumpulan data berupa tes dilakukan sebanyak dua kali, yaitu, sebelum penerapan model pembelajaran kooperatif STAD dan sesudah penerapan model pembelajaran kooperatif STAD.

Seorang siswa dikatakan telah tuntas belajar apabila telah mencapai ketuntasan belajar dengan prosentase $65 \%$ ke atas. Sedangkan ketuntasan klasikal tercapai apabila paling sedikit $75 \%$ siswa di kelas tersebut telah tuntas belajar (Djamarah, 2005:263). Data ini dianalisis dengan menggunakan rumus:

$X=\frac{\sum x i}{n}$
Keterangan:

$X \quad=$ rata-rata kelas

$\sum x i=$ jumlah nilai seluruh siswa

$n \quad=$ jumlah seluruh siswa

Dari tabel diatas, maka untuk mengetahui ketuntasan belajar siswa kelas V SD Negeri Dinoyo I Malang dalam pembelajaran IPS dengan Kerajaan dan Peninggalan Hindu di Indonesia, dapat menggunakan prosentase berikut ini :

$P=\frac{n}{N} \times 100 \%$

Keterangan:

$P=$ prosentase ketuntasan

$n=$ jumlah frekwensi yang tuntas belajar

$N=$ jumlah seluruh siswa (Suharsini, Arikunto Dalam Amalia 2001: 34)

Hasil Observasi aktivitas guru dapat dinilai dari

$N A=\frac{\text { jumlah nilai }}{\text { jumlah aspek }}$

Keterangan:

$8,1-10=$ Sangat memuaskan

$6,1-8=$ Memuaskan

$4,1-6=$ Cukup Memuaskan

$2,1-4=$ Kurang memuaskan

$0-2=$ Sangat tidak

memuaskan

\section{HASIL DAN PEMBAHASAN}

Hasil tes akhir hasil belajar pada kelas memberikan hasil sebagai berikut.

Siklus 1

Tabel 1 Hasil Belajar Siswa

\begin{tabular}{|c|c|c|c|c|}
\hline \multirow[b]{2}{*}{ No } & \multirow[b]{2}{*}{$\begin{array}{l}\text { Nama } \\
\text { Siswa }\end{array}$} & \multirow[b]{2}{*}{$\begin{array}{l}\mathbf{L} \\
/ \\
\mathbf{P}\end{array}$} & \multicolumn{2}{|c|}{ Hasil Belajar Siswa } \\
\hline & & & $\begin{array}{l}\text { Sebelum } \\
\text { menggun } \\
\text { akan } \\
\text { model } \\
\text { pembelaj } \\
\text { aran } \\
\text { kooperat } \\
\text { if STAD }\end{array}$ & $\begin{array}{l}\text { Sesudah } \\
\text { menggun } \\
\text { akan } \\
\text { model } \\
\text { pembelaj } \\
\text { aran } \\
\text { kooperati } \\
\text { f STAD }\end{array}$ \\
\hline 1. & Didit & $\mathrm{L}$ & 40 & 70 \\
\hline 2. & Norma & $\mathrm{P}$ & 50 & 70 \\
\hline
\end{tabular}




\section{INTELIGENSI: Jurnal Ilmu Pendidikan | 2018-1}

\begin{tabular}{|l|l|l|l|l|}
\hline 3. & $\begin{array}{l}\text { Priyata } \\
\text { ma }\end{array}$ & L & 60 & 80 \\
\hline 4. & Agung & L & 20 & 70 \\
\hline 5. & $\begin{array}{l}\text { Andhin } \\
\text { i }\end{array}$ & P & 100 & 100 \\
\hline 6. & Ahmad & P & 50 & 70 \\
\hline 7. & Bima & L & 40 & 70 \\
\hline 8. & Ema & P & 60 & 80 \\
\hline 9. & Firna & P & 20 & 70 \\
\hline 10. & Ilham & L & 40 & 60 \\
\hline 11. & Iffah & P & 40 & 70 \\
\hline 12. & Intan & P & 40 & 70 \\
\hline 13. & Luly & P & 50 & 70 \\
\hline 14. & Lestari & P & 40 & 70 \\
\hline 15. & Meli & P & 20 & 80 \\
\hline 16. & $\begin{array}{l}\text { Muham } \\
\text { mad }\end{array}$ & L & 60 & 80 \\
\hline 17. & $\begin{array}{l}\text { Muh } \\
\text { Habibi }\end{array}$ & L & 50 & 90 \\
\hline 18. & $\begin{array}{l}\text { Nungk } \\
\text { y }\end{array}$ & P & 100 & 100 \\
\hline 19. & $\begin{array}{l}\text { Rosiya } \\
\text { h }\end{array}$ & P & 50 & 70 \\
\hline 20. & Riska & P & 60 & 80 \\
\hline 21. & Sonny & L & 60 & 80 \\
\hline 22. & Tomi & L & 90 & 80 \\
\hline 23. & Yaday & L & 70 & 90 \\
\hline 24. & $\begin{array}{l}\text { Nia } \\
\text { Mayasa } \\
\text { ri }\end{array}$ & P & 90 & 80 \\
\hline 25. & Vadilla & P & 70 & 80 \\
\hline 26. & Alfiya & L & 60 & 70 \\
\hline Rata-rata Kelas & $\mathbf{5 5}$ & $\mathbf{7 6 , 9 2}$ \\
\hline & & & \\
\hline
\end{tabular}

b. Sesudah menggunakan model pembelajaran kooperatif STAD

$>$ Prosentase nilai $80-100=\frac{13}{26} x$ $100 \%=50 \%$

$>$ Prosentase nilai $60-79=\frac{13}{26} x$ $100 \%=50 \%$

$>$ Prosentase nilai $0-59=\frac{0}{26} \quad x$ $100 \%=0 \%$

Tabel 2 Observasi Aktivitas Guru

\begin{tabular}{|c|c|c|c|c|c|c|c|c|c|c|c|}
\hline \multirow{3}{*}{\begin{tabular}{|l} 
Kegi \\
atan \\
pem \\
belaj \\
aran
\end{tabular}} & \multirow{3}{*}{$\begin{array}{l}\text { Aktifitas } \\
\text { guru }\end{array}$} & \multicolumn{5}{|c|}{ Pengamat I } & \multicolumn{5}{|c|}{$\begin{array}{l}\text { Pengamat } \\
\text { II }\end{array}$} \\
\hline & & \multicolumn{5}{|c|}{ Nilai } & \multicolumn{5}{|c|}{ Nilai } \\
\hline & & 5 & 4 & 3 & 2 & 1 & 5 & 4 & 3 & 2 & 1 \\
\hline \multirow{3}{*}{$\begin{array}{l}\text { Kegi } \\
\text { atan } \\
\text { Awal }\end{array}$} & $\begin{array}{l}\text { Menarik } \\
\text { perhatian } \\
\text { siswa }\end{array}$ & & $\sqrt{ }$ & & & & $\sqrt{ }$ & & & & \\
\hline & $\begin{array}{l}\text { Menimbul } \\
\text { kan } \\
\text { motivasi }\end{array}$ & $\sqrt{ }$ & & & & & $\sqrt{ }$ & & & & \\
\hline & $\begin{array}{l}\text { Memberi } \\
\text { acuan / } \\
\text { menyampa } \\
\text { ikan } \\
\text { tujuan } \\
\text { pembelaja } \\
\text { ran }\end{array}$ & $\sqrt{ }$ & & & & & $\sqrt{ }$ & & & & \\
\hline \multirow{4}{*}{$\begin{array}{l}\text { Kegi } \\
\text { atan } \\
\text { Inti }\end{array}$} & $\begin{array}{l}\text { Menyajika } \\
\mathrm{n} \\
\text { informasi }\end{array}$ & $\sqrt{ }$ & & & & & $\sqrt{ }$ & & & & \\
\hline & $\begin{array}{l}\text { Mengorga } \\
\text { nisasikan } \\
\text { siswa } \\
\text { dalam } \\
\text { kelompok } \\
\text { belajar }\end{array}$ & $\sqrt{ }$ & & & & & $\sqrt{ }$ & & & & \\
\hline & $\begin{array}{l}\text { Membimb } \\
\text { ing } \\
\text { kelompok } \\
\text { belajar }\end{array}$ & $\sqrt{ }$ & & & & & $\sqrt{ }$ & & & & \\
\hline & $\begin{array}{l}\text { Menyebar } \\
\text { kan } \\
\text { kesempata }\end{array}$ & & $\sqrt{ }$ & & & & & $\sqrt{ }$ & & & \\
\hline
\end{tabular}




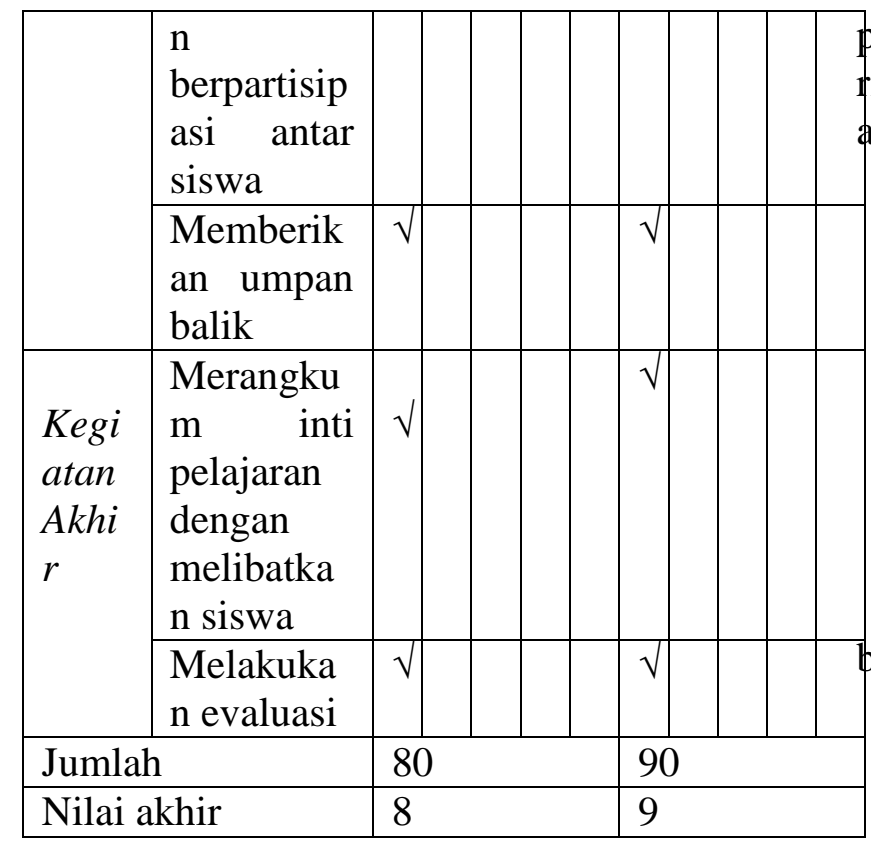

Dengan memperhatikan hasil tes sebelum menerapkan model pembelajaran kooperatif STAD pada mata pelajaran IPS kelas V SD Negeri Jartunggal II/451 Surabaya, maka nilai rata-rata yang diperoleh siswa adalah kurang memuaskan. Hal ini dapat dilihat pada kriteria penilaian di bawah ini, yaitu :

a. Sangat memuaskan (4 orang, atau 15,3 $\%)$, dengan nilai $(80-100)$

b. Memuaskan (8 orang, atau $30 \%$ ), dengan nilai $(60-79)$

c. Tidak memuaskan (14 orang, atau 54 $\%)$, dengan nilai $(0-59)$

Dari hasil analisis tersebut, maka peneliti perlu mangadakan suatu peningkatan hasil belajar IPS pada kelas V SD Negeri Dinoyo I Malang melalui penerapan model pembelajaran kooperatif tipe STAD. Dan dapat dilihat bahwa setelah menggunakan model pembelajaran kooperatif STAD, maka hasil tes mata pelajaran IPS pada siswa kelas V SD Negeri Dinoyo I Malang mengalami suatu perubahan. Hal ini terlihat pada rata-rata kelas yang sebelumnya 55 mengalami peningkatan menjadi 76,92.

Untuk mengetahui peningkatan hasil belajar IPS pada siswa kelas V SD Negeri Dinoyo I Malang dalam materi Kerajaan dan Peninggalan Hindu di Indonesia, maka peneliti akan menguraikannya secara lebih tinci, sebagai berikut:

a. Siswa yang mendapatkan kriteria sangat memuaskan dengan perolehan nilai 80100, sebelum penerapan model pembelajaran kooperatif STAD adalah sebanyak 4 orang siswa, dengan prosentase 15,3\%. Namun setelah penerapan model pembelajaran kooperatif STAD, jumlah siswa yang memperoleh nilai 80-100 mengalami peningkatan menjadi 13 orang, dengan prosentase $50 \%$.

Siswa yang mendapatkan kriteria memuaskan dengan perolehan nilai 6079, sebelum penerapan model pembelajaran kooperatif STAD adalah sebanyak 8 orang siswa, dengan prosentase $30 \%$. Namun setelah penerapan model pembelajaran kooperatif STAD, jumlah siswa yang memperoleh nilai 60-79 bertambah menjadi 13 orang, dengan prosentase $46,15 \%$.

c. Siswa yang mendapatkan kriteria tidak memuaskan dengan perolehan nilai 0 59, sebelum penerapan model pembelajaran kooperatif STAD adalah sebanyak 14 orang siswa, dengan prosentase $54 \%$. Namun setelah penerapan model pembelajaran kooperatif STAD, maka jumlah siswa yang memperoleh nilai 0-59 menjadi tidak ada atau 0 , dengan prosentase $0 \%$.

Berdasarkan hasil pengamatan mengenai aktivitas guru selama proses penerapan model pembelajaran kooperatif STAD dalam pembelajaran IPS di kelas V SD Negeri Dinoyo I Malang, maka diperoleh data sebagai berikut :

- Pada saat membuka kegiatan pembelajaran, guru berhasil menarik perhatian siswa, menimbulkan motivasi siswa, dan memberi acuan atau menyampaikan tujuan pembelajaran dengan baik, sehingga memperoleh point rata-rata 4. 
- Pada inti kegiatan pembelajaran guru dapat menyajikan informasi, mengorganisasikan siswa dalam kelompok belajar, Membimbing kelompok belajar, Menyebarkan kesempatan berpartisipasi antar siswa, dan Memberikan umpan balik secara baik, sehingga memperoleh point ratarata 5.

- Pada akhir kegiatan pembelajaran, guru berhasil Merangkum inti pelajaran dengan melibatkan siswa, dan melakukan evaluasi untuk melihat sejauh mana kemampuan siswa dalam menguasai materi yang disampaikan, mulai dari awal hingga akhir pembelajaran, sehingga memperoleh poin rata-rata 5 .

Jadi dapat disimpulkan bahwa aktivitas guru selama menerapkan model pembelajaran kooperatif STAD dalam pembelajaran IPA di kelas V SD Negeri Dinoyo I Malang begitu memuaskan, yakni dengan perolehan nilai akhir berjumlah 9. Akan tetapi nilai tersebut masih dipandang belum tuntas karena bila anak mendapatkan nilai dbawah nilai yang diharapkan oleh peneliti. Dalam hal itu peneliti sudah mengetahui masalah terhadap anak tersebut masih belum mengerti materi dan anak tersebut tidak mu berkembang maka dengan begitu peneliti mengadakan siklus yang ke II agar pembelajaran IPS kelas V bab Kerajaan dan Peninggalan Hindu Budha sudah bisa dikatakan tunts atau sangat memuaskan.

Pada tahap ini dilaksanakan observasi terhadap pelaksanaan pembelajaran dengan menggunakan lembar observasi untuk mengetahui perkembangan aktivitas siswa dan guru. Kegiatan observasi siklus I dilaksanakan pada saat pembelajaran berlangsung yang dilakukan oleh guru kelas dan atau teman sejawat sebagai observer. Berikut ini adalah aktivitas yang diamati :

1) Aktivitas guru dalam dalam menyampaikan proses pembelajaran.
2) Aktivitas siswa dalam mengikuti proses pembelajaran.

3) Refleksi

Pada tahap ini, kegiatan yang dilakukan adalah :

- Merangkum hasil observasi.

- Menganalisis hasil belajar siswa.

- Diskusi dengan observer untuk mengetahui keberhasilan dan kegagalan pada siklus I untuk diperbaiki pada pelaksanaan siklus berikutnya.

- Jika penelitian belum mencapai keberhasilan, maka penelitian dilanjutkan pada siklus berikutnya.

Siklus 2

Hasil tes akhir hasil belajar pada kelas memberikan hasil sebagai berikut. Dari prosentase tersebut, maka bisa dilihat prosentase ketuntasan siswa dalam pembelajaran IPS dengan materi Kerajaan dan Peninggalan Hindu di Indonesia sebelum dan sesudah menggunakan model pembelajaran kooperatif STAD, adalah sebagai berikut :

- Sebelum menggunakan model pembelajaran kooperatif STAD

Prosentase nilai $80-100=\frac{4}{26} \quad x$ $100 \%=15,3 \%$

Prosentase nilai $60-79=\frac{9}{26} x$ $100 \%=34,7 \%$

Prosentase nilai $0-59=\frac{13}{26} x$ $100 \%=50 \%$

- Sesudah menggunakan model pembelajaran kooperatif STAD

Prosentase nilai $80-100=\frac{20}{26} x$ $100 \%=76,92 \%$

Prosentase nilai $60-79=\frac{3}{26} x$ $100 \%=11,54 \%$

Prosentase nilai $0-59=\frac{3}{26} \quad x$ $100 \%=11,54 \%$ 
Tabel 5 Aktivitas Guru

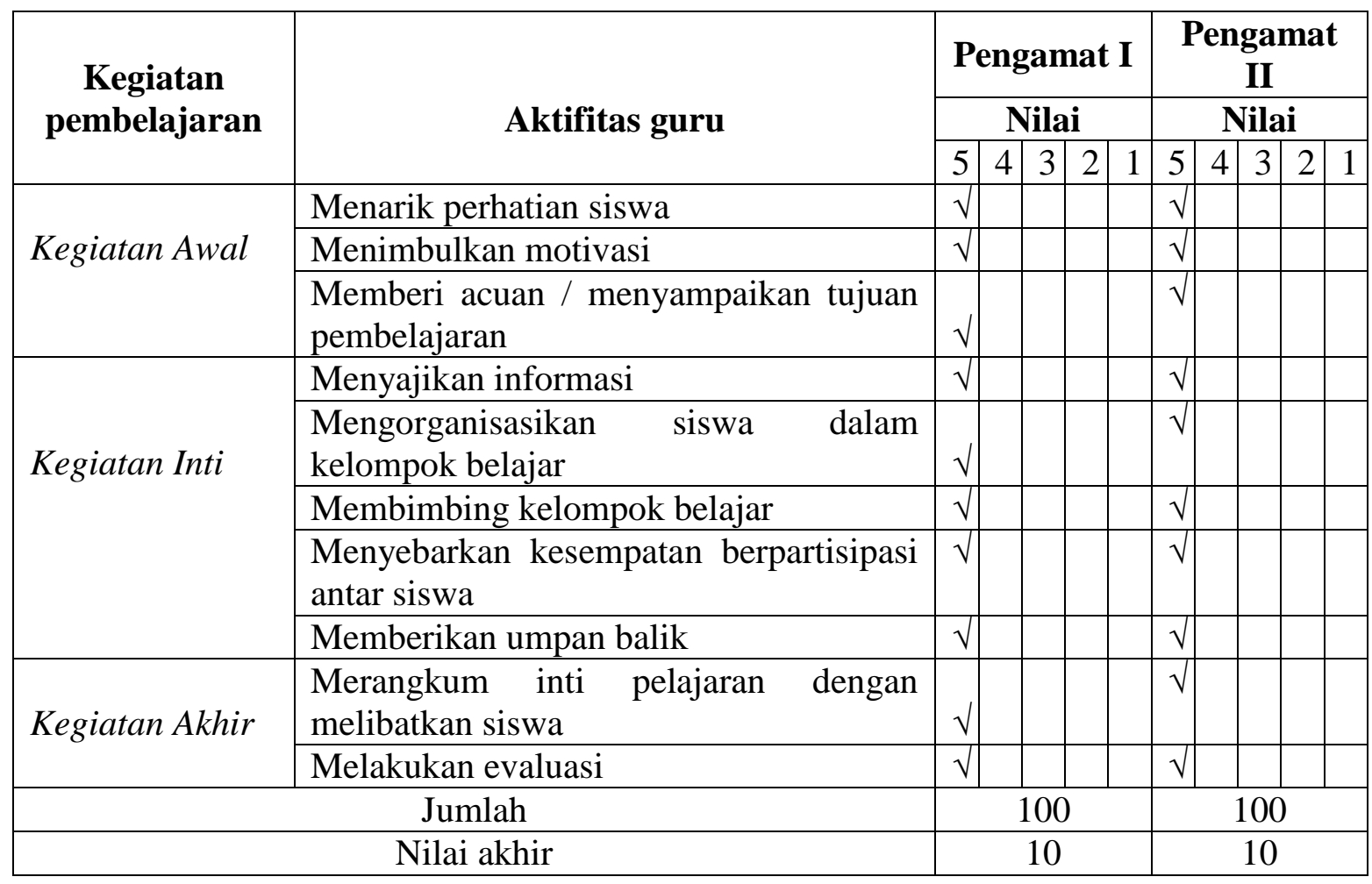

Dengan memperhatikan hasil tes sebelum menerapkan model pembelajaran kooperatif STAD pada mata pelajaran IPS kelas V SD Negeri Dinoyo I Malang, maka nilai rata-rata yang diperoleh siswa adalah kurang memuaskan. Hal ini dapat dilihat pada kriteria penilaian di bawah ini, yaitu :

a. Sangat memuaskan (4 orang, atau $15,3 \%)$, dengan nilai (80 - 100)

b. Memuaskan (9 orang, atau 34,7\%), dengan nilai $(60-79)$

c. Tidak memuaskan (13 orang, atau $50 \%)$, dengan nilai $(0-59)$

Dari hasil analisis tersebut, maka peneliti perlu mangadakan suatu peningkatan hasil belajar IPS pada kelas V SD Negeri Dinoyo I Malang melalui penerapan model pembelajaran kooperatif tipe STAD. Dan dapat dilihat bahwa setelah menggunakan model pembelajaran kooperatif STAD, maka hasil tes mata pelajaran IPS pada siswa kelas V SD Negeri Dinoyo I Malang mengalami suatu perubahan. Hal ini terlihat pada rata-rata kelas yang sebelumnya 50 mengalami peningkatan menjadi 84,61

Untuk mengetahui peningkatan hasil belajar IPS pada siswa kelas V SD Negeri Dinoyo I Malang dalam materi Kerajaan dan Peninggalan Hindu di Indonesia, maka peneliti akan menguraikannya secara lebih rinci, sebagai berikut :

a. Siswa yang mendapatkan kriteria sangat memuaskan dengan perolehan nilai 80 100, sebelum penerapan model pembelajaran kooperatif STAD adalah sebanyak 4 orang siswa, dengan prosentase $15,3 \%$. Namun setelah penerapan model pembelajaran kooperatif STAD, jumlah siswa yang memperoleh nilai 80-100 mengalami peningkatan menjadi 20 orang, dengan prosentase $76,92 \%$.

b. Siswa yang mendapatkan kriteria memuaskan dengan perolehan nilai 6079, sebelum penerapan model pembelajaran kooperatif STAD adalah sebanyak 9 orang siswa, dengan prosentase $34,7 \%$. Namun setelah 


\section{INTELIGENSI: Jurnal Ilmu Pendidikan}

penerapan model pembelajaran kooperatif STAD, jumlah siswa yang memperoleh nilai 60-79 bertambah menjadi 3 orang, dengan prosentase $11,53 \%$.

c. Siswa yang mendapatkan kriteria tidak memuaskan dengan perolehan nilai 0-59, sebelum penerapan model pembelajaran kooperatif STAD adalah sebanyak 13 orang siswa, dengan prosentase $50 \%$. Namun setelah penerapan model pembelajaran kooperatif STAD, maka jumlah siswa yang memperoleh nilai 0 59 menjadi tidak ada atau 3, dengan prosentase $11,53 \%$.

\section{Hasil Observasi}

Berdasarkan hasil pengamatan mengenai aktivitas guru selama proses penerapan model pembelajaran kooperatif STAD dalam pembelajaran IPS di kelas V SD Negeri Dinoyo I Malang, maka diperoleh data sebagai berikut :

Pada saat membuka kegiatan pembelajaran, guru berhasil menarik perhatian siswa, menimbulkan motivasi siswa, dan memberi acuan atau menyampaikan tujuan pembelajaran dengan baik, sehingga memperoleh point rata-rata 5 .

Pada inti kegiatan pembelajaran guru dapat menyajikan informasi, mengorganisasikan siswa dalam kelompok belajar, Membimbing kelompok belajar, Menyebarkan kesempatan berpartisipasi antar siswa, dan Memberikan umpan balik secara baik, sehingga memperoleh point ratarata 5 .

> Pada akhir kegiatan pembelajaran, guru berhasil Merangkum inti pelajaran dengan melibatkan siswa, dan melakukan evaluasi untuk melihat sejauh mana kemampuan siswa dalam menguasai materi yang disampaikan, mulai dari awal hingga akhir pembelajaran, sehingga memperoleh poin rata-rata 5 .

Jadi dapat disimpulkan bahwa aktivitas guru selama menerapkan model pembelajaran kooperatif STAD dalam pembelajaran IPS di kelas V SD Negeri Dinoyo I Malang begitu memuaskan, yakni dengan perolehan nilai akhir berjumlah 10. Akan tetapi nilai tersebut masih dipandang belum tuntas karena masih ada 3 anak mendapatkan nilai dbawah nilai yang diharapkan oleh peneliti. Dalam hal itu peneliti sudah dapat dikatakan berhasil dengan siknifikan dari nilai yang diperoleh dari siklus ke 2 dan dalam siklus ke 2 ini sangat memuaskan bagi peneliti dan bagi sekolah.

\section{KESIMPULAN}

Berdasarkan hasil penelitian dan pembahasan tentang Penerapan Model Pembelajaran Kooperatif tipe STAD untuk meningkatkan hasil belajar IPS pada siswa kelas V SD Negeri Dinoyo I Malang, maka dapat disimpulkan bahwa :

1. Penerapan model pembelajaran kooperatif STAD dapat meningkatkan hasil belajar IPS pada siswa kelas V SD Negeri Dinoyo I Malang khususnya dalam materi Kerajaan dan Peninggalan Hindu di Indonesia. Hal ini dapat dilihat dari perolehan nilai rata-rata dimana sebelumnya 50 berubah menjadi 84,61 setelah penerapan model pembelajaran kooperatif STAD. Perbandingan tersebut menunjukan bahwa hasil belajar IPS dengan menggunakan model pembelajaran kooperatif STAD mengalami suatu peningkatan yang sangat baik, dibandingkan sebelum menerapkan model pembelajaran kooperatif STAD

2. Aktivitas guru selama menerapkan model pembelajaran kooperatif STAD dalam pembelajaran IPS di kelas V SD Negeri Dinoyo I Malang, juga terlihat dengan kriteria sangat memuaskan. Hal 
ini dilihat dari perolehan nilai rata-rata berjumlah 5 dan nilai akhir berjumlah 10

\section{DAFTAR PUSTAKA}

Depdiknas. (2004). Pedoman Penilaian, Jakarta: Departemen Pendidikan Nasional.

Depdiknas. (2006). Kurikulum Standar Kompetensi Mata Pelajaran IPS di $S D$. Jakarta: Departemen Pendidikan Nasional.

Djamarah, Bahri Syaiful.2014.Strategi Belajar Mengajar.Jakarta:Rineka Cipta

Herawati. (2010). Meningkatkan Kemampuan Siswa Kelas V SDN Jatinangor Bandung dalam Memahami Kegiatan Ekonomi di Indonesia dengan Menggunakan Model Pembelajaran Kooperatif Tipe STAD pada Pembelajaran IPS Tahun Pelajaran 2010/2011. Skripsi tidak diterbitkan. Bandung: UPI.

Nugraha, Garin Dian. 2014. "Peningkatan Hasil Belajar Mata Pelajaran IPS
Arikunto, Suharsimi, dkk. 2013. Penelitian Tindakan Kelas. Jakarta: PT Bumi Aksara.

dengan Strategi Quantum Learning Bagi Siswa kelas IV SDN Made 4 Lamongan”. Jurnal Penelitian Pendidikan Guru Sekolah Dasar. Vol. 02 (02): hal. 2

Slavin. Robert E, 2008, Cooperatif Learning. Jakarta: Nusa Media.

Sudjana, N. 2013. Penilaian Hasil Proses Belajar Mengajar. Bandung: Sinar Baru Algesindo.

Sudjana. (2005). Metode Statistika. Bandung: Tarsito.

Sugiarto. (2009). Workshop Pendidikan Matematika 1. Semarang: Jurusan Matematika FMIPA UNNES.

Trianto, 2015. Strategi-strategi Pembelajaran Inovatif Berbasis Konstruktivisme. Jakarta : Perpustakaan Nasional Katalog Dalam Terbitan (KD 